\title{
Molecular diagnosis of COVID-19: Current situation and trend in China (Review)
}

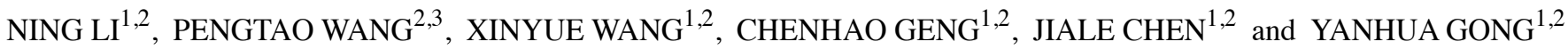 \\ ${ }^{1}$ Institute of Disaster Medicine, Tianjin University; ${ }^{2}$ Tianjin Key Laboratory of Disaster Medicine Technology, \\ Tianjin 300072; ${ }^{3}$ General Hospital of Tianjin Medical University, Tianjin 300070, P.R. China
}

Received April 23, 2020; Accepted July 29, 2020

DOI: $10.3892 /$ etm.2020.9142

\begin{abstract}
COVID-19 is caused by a novel coronavirus (2019-nCoV or SARS-CoV-2) and has become a global public health emergency. Rapid and accurate molecular diagnostic technologies are crucial for the screening, isolation, treatment, prevention and control of COVID-19. Currently, nucleic acid detection-based techniques and rapid diagnostic tests that detect antigens or antibodies specific to 2019-nCoV infections are the primary diagnostic tools. China National Medical Products Administration has opened a special channel for approval of new pharmaceuticals owing to urgent clinical needs, with 18 nucleic acid detection kits, 11 protein detection kits and 1 sequencing-related equipment and supporting software having been approved until April 23, 2020. The current review summarizes the application situation, advantages, disadvantages and associated technology improvement trends of molecular diagnostics for COVID-19 in China, identifies knowledge gaps and indicates future priorities for research in this field. The most effective way to prevent and control COVID-19 is early detection, diagnosis, isolation and treatment. In the clinical application of molecular diagnosis technology, it is necessary to combine pathogenic microbiology, immunology and other associated detection technologies, advocate the combination of multiple technologies, determine how they complement each other, enhance practicability and improve the ability of rapid and accurate diagnosis and differential diagnosis of COVID-19.
\end{abstract}

\section{Contents}

1. Introduction

2. Current molecular diagnostic methods of 2019-nCoV, pros and cons and clinical applications

Correspondence to: Dr Yanhua Gong, Institute of Disaster Medicine, Tianjin University, 92 Weijin Road, Tianjin 300072, P.R. China

E-mail: gongyanhua@tju.edu.cn

Key words: in vitro diagnosis, molecular diagnosis, 2019-nCoV, COVID-19, nucleic acid detection, protein detection
3. Future trends

4. Conclusion

\section{Introduction}

In December 2019, a novel viral pneumonia case due to unknown causes was reported in Wuhan, China, with evidence of human-to-human transmission (1). On January 12, 2020, the World Health Organization proposed to name the novel coronavirus causing the pneumonia epidemic '2019 novel coronavirus (2019-nCoV)' (1-3) and on February 11, the disease caused by the coronavirus was termed 'Coronavirus Disease 2019', abbreviated to 'COVID-19' (4). On the same day, the Coronavirus Study Group (CSG) of the International Committee on Taxonomy of Viruses issued a statement recommending that 2019-nCov be classified as severe acute respiratory syndrome coronavirus 2 (SARS-CoV-2) (5). However, on February 12, Science (6) reported that the World Health Organization was not satisfied with the name SARS-CoV-2 as it would cause unnecessary panic to certain people, particularly in Asia, where the SARS epidemic was most severe in 2003 (6). On February 18, certain Chinese researchers in the field of virology contributed to the name issue (7). Those researchers stated that 2019-nCoV is different from SARS coronavirus and, therefore, the name SARS-CoV-2 is misleading and should have a different name. On March 2, the CSG published a naming statement for the novel coronavirus in Nature Microbiology, describing the naming method and process of the novel coronavirus and introducing common problems in virus classification (8).

$2019-\mathrm{nCoV}$ is a single stranded RNA, positive chain enveloped $\beta$-coronavirus (9). The viral particles are round or oval, often polymorphous, with a diameter of 60-140 nm (1). Its genomic characteristics are significantly different from SARS-CoV and Middle East Respiratory Syndrome Coronavirus (MERS-CoV) $(9,10)$. Current research has demonstrated 2019-nCoV has $>85 \%$ homology with bat SARS-like coronavirus (bat-SL-CoVZC45) (9). According to the National Center for Biotechnology Information database (https://www.ncbi.nlm.nih.gov/nuccore/1798174254/; version no.: NC_045512.2; release date July 18th, 2020), the genomic sequence of 2019-nCoV (NC_045512.2) is a positive-sense single-stranded RNA with $29903 \mathrm{bp}$. Wu et al (11) reported that 
it has 14 open reading frames (Orfs) and encodes 27 proteins. Orflab and orfla genes located at the 5'end of the genome encode pplab and ppla proteins, respectively. The 3 'end of the genome contains four structural proteins: Spike glycoprotein (S), small envelope protein (E), membrane glycoprotein (M), nucleocapsid protein (N) and accessory proteins (11) (Fig. 1). $\mathrm{S}$ protein serves a key role in the recognition and binding of host cell surface receptors and mediates the fusion of viral envelopes and cell membranes (12). M protein is involved in the formation and budding of the viral envelope. E protein binds to cell envelopes (13). These three proteins are located on the phospholipid membrane of virus, which envelops viral RNA, maintaining the stability of genome and resisting the degradation of RNA enzymes in the human body (14).

Novel coronavirus pneumonia is a new infectious disease that humans are not immune to. This means people are generally susceptible to infection. Presently, the main source of infection occurs in patients with viral infections; however, asymptomatic infected individuals may also become the source of infection (15). Additionally, incubated patients may be infectious and the virus has even been detected in patients in the recovery period, indicating that they may also be infectious to a certain degree (16). A recent study demonstrated positive reverse transcription PCR (RT-PCR) results in patients recovering from COVID-19, indicating that certain recovered patients may still be carriers of the virus (17). Although respiratory droplets and contact transmission are the main transmission routes of 2019-nCoV, viral particles have been detected in the stool of confirmed patients in several places, such as Beijing and Washington, suggesting that there is a risk of fecal-oral transmission $(18,19)$. Additionally, aerosol transmission and mother-to-child transmission need to be confirmed.

Since the outbreak of novel coronavirus pneumonia, the efficient and accurate laboratory diagnosis of 2019-nCoV is crucial for the effective prevention and control of the epidemic. Since March 3, 2020, three methods have been used for the diagnosis of novel coronavirus pneumonia: i) Detection of positive 2019-nCoV nucleic acids by RT-PCR; ii) viral gene sequencing to detect known 2019-nCoV sequences; and iii) the identification of positive 2019-nCoV-specific IgM and IgG antibodies in serum (15). At the start of the epidemic, RT-PCR kits were developed rapidly and had the earliest clinical application; however, the accuracy of RT-PCR results is only $30-50 \%$ at present (20). This is due to variety of factors, including poor sample quality, such as throat swabs and other respiratory samples, samples being collected too early or too late, samples not being properly preserved, transported and/or processed, the technology itself, which would be affected by virus mutation and PCR inhibition. Furthermore, it takes 6-8 $\mathrm{h}$ to complete the entire process. The test results need to be rechecked when the results from different areas are inconsistent or when doctors determine whether the patient is cured or discharged. Additionally, repeated verification experiments double testing times. Approval for antibody detection kits would markedly ease the pressure and risk of nucleic acid detection.

Therefore, due to the large number of suspected 2019-nCoV patients in epidemic areas, it is crucial to shorten diagnosis and treatment time, improve the accuracy and speed of detection, promote the screening, isolation and treatment of epidemic conditions and develop innovative rapid molecular diagnostic techniques in vitro.

\section{Current molecular diagnostic methods of 2019-nCoV, pros and cons and clinical applications}

Nucleic acid detection technology. Nucleic acid detection is an important diagnostic tool for the clinical diagnosis, segregation, rehabilitation and discharge of patients, and was also the 'gold standard' for the detection of 2019-nCoV infection in the early stage of the epidemic (21). Current nucleic acid detection methods include RT-PCR, isothermal amplification and high-throughput sequencing. At present, specimens tested by commercial nucleic acid kits mainly comprise throat swabs, oropharyngeal swabs, nasopharyngeal swabs, sputum and alveolar lavage fluid $(15,22)$.

RT-PCR technology. Since the development of the 2019-nCoV epidemic, China has recommended RT-PCR technology as a guideline for the COVID-19 diagnosis and treatment program (21). The Chinese Center for Disease Control and Prevention recommends the use of primers and fluorescent probes (FAM, BHQ1 and TAMRA) targeting 2019-nCoV ORF1ab and nucleocapsid protein $(\mathrm{N})$ gene regions (Table I) (23).

The Institute of Viral Prevention and Control of the Chinese Center for Disease Control and Prevention recommends a $\mathrm{Ct}$ value of RT-PCR $<37$ showing an exponential curve, which indicates positive infection. It is recommended to repeat experiments for results between 37-40 and if the $\mathrm{Ct}$ value is $<40$ after repeat experiments, it is still considered to be positive. No $\mathrm{Ct}$ value or $\mathrm{Ct}>40$ is considered to be negative (23). Currently, 11 nucleic acid detection kits for the ORF1ab, $\mathrm{N}$ and E regions have been approved by the China National Medical Products Administration (Table II) (22) that use RT-PCR to test patients' throat swabs, oropharyngeal swabs, nasopharyngeal swabs, sputum, alveolar lavage fluid and other samples. These provide favorable guarantees for early diagnosis and early isolation of patients with 2019-nCoV (22).

The Department of Clinical Laboratory of the Third Hospital of Chongqing Municipal People's Hospital compared the detection performance of 2019-nCoV for six of the kits (Shengxiang Biotechnology 2019-nCOV rapid nucleic detect kit, Beijing Ka You Di 2019-nCoV ORF1ab/N gene RNA detection kit for nucleic acid-free extraction, Shuoshi Biotechnology 2019-nCOV detection kit, Zhongyuan 2019-nCOV nucleic detect kit, Zhong Shan An Da 2019-nCoV ORF1ab/N nucleic detection kit and Beijing Zhuo Cheng Hui Xin 2019-nCoV ORF1ab/N gene double fluorescent RT-PCR kit) and reported that the detection capabilities of each kit for weakly positive samples were different (24). Furthermore, certain kits were able to double-positively detect Orflab and N, while other kits could only detect one of them.

At present, RT-PCR nucleic acid detection serves an irreplaceable role in the diagnosis of $2019-\mathrm{nCoV}$ and is the most important molecular diagnostic method in the early stage of the epidemic (21). However, there are limitations due to tedious, time-consuming operation, required biosafety laboratories ranked Class II or above centralized inspection and shortage 
Table I. Recommended 2019 novel coronavirus nucleic acid detection primers and probe sequences for virus prevention and control by the Chinese Center for Disease Control and Prevention.

\begin{tabular}{lll}
\hline Item & \multicolumn{1}{c}{ Orf1ab } & \multicolumn{1}{c}{$\mathrm{N}$} \\
\hline Forward & CCCTGTGGGTTTTACACTTAA & GGGGAACTTCTCCTGCTAGAAT \\
Reverse & ACGATTGTGCATCAGCTGA & CAGACATTTTGCTCTCAAGCTG \\
Fluorescent probe & 5'-FAM-CCGTCTGCGGTATGTGGAAAG & 5'-FAM-TTGCTGCTGCTTGACAGATT-TAMRA-3' \\
& GTTATGG-BHQ1-3' & \\
\hline
\end{tabular}

Orf, open reading frame; N, nucleocapsid protein; FAM, 6-carboyfluorescin; TAMRA, tetramethylrhodamine.

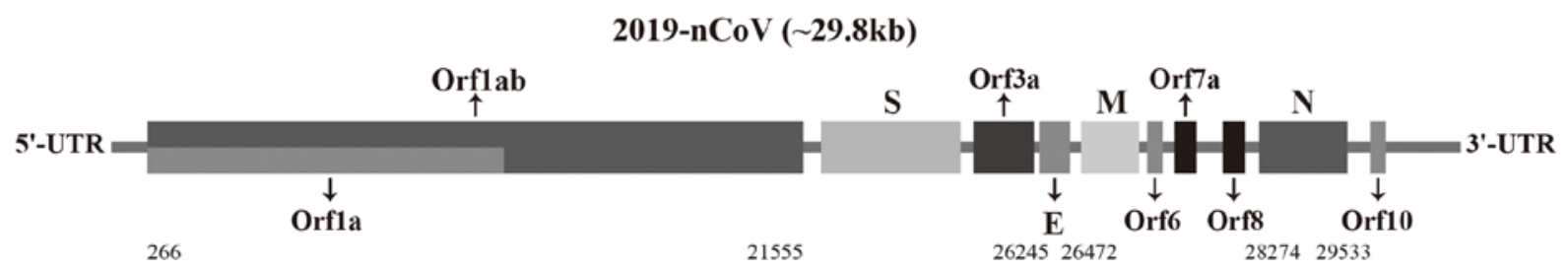

Figure 1. 2019-nCoV genome isolated from patients with novel coronavirus pneumonia in Wuhan, China. The 2019-nCoV molecular diagnostic targets mainly include the sequences of genes such as Orf1ab, N, E and S in the viral genome and their protein expression products. 2019-nCOV, 2019 novel coronavirus; Orf, open reading frame; $\mathrm{N}$, nucleocapsid protein; E, small envelope protein; S, spike glycoprotein; M, membrane glycoprotein; UTR, untranslated region.

of personnel and qualified biosafety sites in the epidemic area (25). Furthermore, there are shortcomings in responding to the rapidly increasing demand for the diagnosis of patients with suspected 2019-nCoV pneumonia and asymptomatic infections $(25,26)$. Additionally, recent research on patients infected with 2019-nCoV demonstrated that the positive rates of early stage nucleic acid detections of oropharyngeal swabs, anal swabs and blood were 53.3, 26.7 and 40\%, respectively, while the positive rate of anal swabs was even higher than oral swabs in the late stage of infection (27). Notably, the actual positive rate is only $30-50 \%$ when collecting suspected patient samples through routine throat swabs at the outpatient fever clinic, with many of the samples producing false-negative results (20), despite the considerable pressure to prevent and control the 2019-nCoV.

High-throughput sequencing technology. Gene sequencing is the most accurate and reliable technology for the detection of viruses and other pathogenic 'emergency' infectious diseases. Additionally, it is the only method to dynamically track genome variation in pathogens (28). In the early stage of the epidemic, the Chinese Center for Disease Control and Prevention identified and analyzed the genome of 2019-nCoV based on second-generation sequencing metagenomics technology (mNGS) within five days and reported that the similarity between the nucleotide sequence of 2019-nCoV and SARS or bat-derived strains were 79 and 96\%, respectively (9).

The China National Medical Products Administration has approved a gene sequencing system (ultra-high-throughput sequencer DNBSEQ-T7), supporting analysis software and nucleic acid detection kits (Table III), which can identify and diagnose coronaviruses, including 2019-nCoV and other infectious respiratory pathogens and enable rapid detection of viral sequences (22). The DNBSEQ-T7 sequencer can complete the entire 2019-nCoV detection process (from sample extraction to result reporting) in $20 \mathrm{~h}$. The sample detection throughput is 50-200 per cycle and each sample can obtain an average data output of $>100 \mathrm{M}$, ensuring highly accurate results for 2019-nCoV detection (29). However, mNGS has the limitations of high equipment and testing costs, long detection cycles, complicated procedures and a lack of standardization. Furthermore, the sequencing depth of certain samples is not always appropriate (29).

Nanopore sequencing is a third-generation genome sequencing technology that provides real-time analysis and rapid insights. It is a physical sequencing technology based on alterations in electrical signals (30). Nanopore sequencing does not require enzymes to amplify samples and directly performs full-length sequencing of 2019-nCoV (30). This method has the advantages of long sequencing length, low cost, high throughput and non-labeling $(30,31)$. However, nanopore sequencing has not yet been approved by the China National Medical Products Administration. Hangzhou Center for Disease Control and Prevention completed the first 2019-nCoV genome assembly using only nanopore data on February 12, 2020 (32). Final assembly results were 100\% consistent with the reference genome without the correction of other sequencing technologies. The development of a real-time and rapid viral genome sequencing solution through nanopore sequencing is expected to become a powerful technology and resource support for combating viral epidemics worldwide (32).

2019-nCov will continue to mutate during the transmission process. An analysis of $1032019-n C o v$ genomic data collected from a public database (Global Initiative on Sharing All Influenza Data; https://www.gisaid.org/) from December 24, 2019 to February 5, 2020 demonstrated that these virus strains underwent a total of 149 point mutations and that most mutations occurred recently (33). If a mutation is located in the primer or probe binding site, the sensitivity and 
accuracy of existing RT-PCR detection kits will be affected. High-throughput sequencing technology can compensate for the limitations of RT-PCR, effectively increase positive rates and monitor possible mutations (31). Furthermore, sequencing could simultaneously providing a more comprehensive pathogen genome analysis of critical illness and patients with complex infections, provide more information about infectious pathogens and identify drug resistance genes to guide clinical medication (34). However, due to the high cost, long procedure times and complex testing processes, it has not become a routine clinical batch testing technology (34).

Isothermal temperature nucleic acid amplification technology and loop-mediated isothermal amplification (LAMP) technology. Developed in 2000, LAMP is a fast and highly specific technology for gene amplification under constant temperature conditions (35). RT Loop-Mediated Isothermal Amplification (RT-LAMP) combines RT with LAMP, can be used directly for RNA detection and has previously been used in the identification of various respiratory RNA viruses, including SARS-CoV and MERS-CoV $(36,37)$. Based on this, by adding a fluorescence quenching probe (QProbe), fluorescence RT-LAMP technology be used for the detection of MERS-CoV (38). In order to make the detection of LAMP amplification products more accurate, the combination of nucleic acid detection and immunogold labeling technology has resulted in an improved RT-LAMP-combined nucleic acid strip detection technology (RT-LAMP-NAD), which has been used for the detection of Ebola virus (39).

On February 25, 2020, the team of Dr Xiushan Yin, the director of the Institute of Applied Biology of Shenyang University of Chemical Technology and the team of Michael B Chancellor at Royal Oak Beaumont published an article about RT-LAMP on MedRxi. The article optimized a specific and accurate detection method for 2019-nCoV and provided multiple primer sequences directed at Orf $1 \mathrm{ab}$ region $(40,41)$. The entire reaction process takes approximately $15-45 \mathrm{~min}(40,41)$. This simple analytical method can be used on biological samples outside of central laboratories to monitor isolated populations or to assist in screening at entrance areas $(40,41)$. Numerous domestic institutions have announced that they have developed a $2019-\mathrm{nCoV}$ isothermal amplification kit, which requires only 'one-time opening and one-step operation', and can complete amplification reactions as fast as $15 \mathrm{~min}$. Test results are fast and easy, and can be seen macroscopically (22). Relevant products have entered the review process of the China National Medical Products Administration and certain products have obtained registration certificates (Table IV) (22).

Although LAMP technology has the advantages of simplicity, sensitivity, specificity, speed and is inexpensive and has low hardware requirements, the development of a kit using this technology is more complicated than an RT-PCR kit and involves multiple pairs of primers (42). Therefore, the development and clinical application of LAMP in 2019-nCoV pneumonia epidemic is slower than RT-PCR.

Isothermal temperature nucleic acid amplification technology and recombinase aided amplification (RAA). RAA technology utilizes recombinases, single-stranded binding proteins and 
Table III. 2019-nCoV sequencing systems, kits and analysis software approved by the China National Medical Products Administration.

\begin{tabular}{|c|c|c|c|c|}
\hline No. & Product name & Company & Approval date & $\begin{array}{l}\text { National medical device } \\
\text { registration certificate no. }\end{array}$ \\
\hline 1 & $\begin{array}{l}\text { New Coronavirus 2019-nCoV } \\
\text { Nucleic Acid Detection Kit } \\
\text { (Joint Probe Anchor Polymerization } \\
\text { Sequencing Method) }\end{array}$ & $\begin{array}{l}\text { Huada Biological Technology } \\
\text { Co., Ltd. }\end{array}$ & 26 January 2020 & 20203400059 \\
\hline 2 & $\begin{array}{l}\text { Gene Sequencing System } \\
\text { (Ultra-high-throughput sequencer } \\
\text { DNBSEQ-T7) }\end{array}$ & $\begin{array}{l}\text { Wuhan Huada Intelligent } \\
\text { Manufacturing Technology } \\
\text { Co., Ltd. }\end{array}$ & 26 January 2020 & 20203220061 \\
\hline 3 & $\begin{array}{l}\text { 2019-nCoV Nucleic Acid Analysis } \\
\text { software }\end{array}$ & $\begin{array}{l}\text { Huada Biological Technology } \\
\text { Co., Ltd. }\end{array}$ & 26 January 2020 & 20203220062 \\
\hline
\end{tabular}

2019-nCoV, 2019 novel coronavirus.

DNA polymerases to perform nucleic acid amplification under isothermal $\left(37^{\circ} \mathrm{C}\right)$ conditions $(43)$.

Using RAA technology, the Institute of Viral Disease Control and Prevention of the Chinese Center for Disease Control and Jiangsu Qitian Gene Biotechnology Co., Ltd. jointly developed a new coronavirus (2019-nCoV) nucleic acid isothermal amplification rapid detection kit. After nucleic acid is extracted, it only takes $8-15 \mathrm{~min}$ to detect 2019-nCoV nucleic acid (44). Following parallel comparison with commercial quantitative PCR (qPCR) kits approved by the China National Medical Product Administration (NMPA), the kits have a $100 \%$ positive compliance rate, a $100 \%$ negative compliance rate and a total compliance rate of $100 \%$, which are equivalent (44). The kit has been evaluated by the First Affiliated Hospital of Zhejiang University School of Medicine (92 clinical samples), Zhejiang Center for Disease Control and Prevention (104 clinical samples) and Jiangsu Province's Center for Disease Control and Prevention (100 samples) (44). The kit is recommended for qualitative detection of clinical 2019-nCoV to identify patients with suspected infection. The kit is considered suitable for use in prefecture-level laboratories and is currently applying for a China NMPA approval number (44).

RAA technology is relatively new in the current nucleic acid detection technology field. The advantage of rapidity, sensitivity and specificity of RAA technology may aid in the detection, screens, isolation for suspected 2019-nCoV infections (43).

Nucleic acid mass spectrometry. Nucleic acid mass spectrometry is a novel type of soft ionized biological mass spectrometry technology that has been developed recently based on atrix Assisted Laser Desorption Ionization-Time Of Flight technology and is very simple and efficient (45). This procedure integrates the high-throughput of chip technology and the high sensitivity of mass spectrometry technology without the requirement for complex biological information analysis and is mainly used for the detection of known mutations (46). A single reaction of nucleic acid mass spectrometry can perform 20-50 PCR amplifications simultaneously and can detect dozens of pathogens at once (46). Nucleic acid mass spectrometry is a very useful tool for the differential diagnosis of respiratory infections (47).

It was previously announced that the successful development of a nucleic acid mass spectrometry kit that can simultaneously detect 2019-nCoV and 20 other common respiratory infection pathogens (48). The detection limit is as low as 100 copies/ml and 96 pieces of single-chip with a manual operation time of $30 \mathrm{~min}$. Furthermore, 1,504 tests can be completed in $24 \mathrm{~h}$ (48). Additionally, the kit can detect other RNA viruses that cause respiratory diseases, including influenza A and B (48).

Nucleic acid mass spectrometry has high throughput analysis, is simple to operate and is inexpensive, nucleic acids are difficult to ionize, are unstable and easily generate fragments (46). This makes it difficult to parse spectrum data. It is necessary to continuously improve the resolution of the detector to promote its use (46).

Protein detection technology. Protein detection technology is mainly divided into pathogen antigen detection and host antibody detection (49). Commonly used methodologies include colloidal gold (50), immunofluorescence chromatography (51), chemiluminescence $(52,53)$ and ELISA (54). The colloidal gold method is easy to operate and can be directly visually interpreted (55). The test can be completed in $15 \mathrm{~min}$ and, therefore, can be used for on-site material acquisition and on-site detection (55). Immunofluorescence chromatography is as easy to operate as colloidal gold and detection is fast; however, it requires instrument interpretation $(51,56)$. The chemiluminescence method generally has high sensitivity and uses a full-automatic immunoanalyzer, which can complete detection without excessive manual operation $(52,53)$. The detection time is generally $\sim 30 \mathrm{~min}$. ELISA can be interpreted using a conventional microplate reader (57). Generally, ELISA exhibits high sensitivity; however, the detection time is longer $(\geq 1.5 \mathrm{~h})$ and there are numerous operating steps (54).

Antigen detection technology. 2019-nCoV gene encodes 4 structural proteins: S, E, M and N. These proteins include multiple 
epitopes (58). Using the principle of specific binding of antigens to antibodies, antibodies can be used to detect the presence of antigens, thereby directly detecting whether samples contain 2019-nCoV (59). The applicable sample type of the antigen detection reagent is generally an infection site sample, such as a throat swab. Currently, several research teams have developed a variety of antigen detection kits, which are awaiting approval from the State Drug Administration (Table V) (22).

The biggest advantages of an antigen detection kit are short detection times and high detection sensitivity (as the detection of virus protein reaches pg levels), providing a simple and sensitive method for the early screening of viral infection (64). However, these kits are qualitative, not quantitative (65). Positive sample results only indicate the presence of coronavirus antigen and other conditions cannot be evaluated (51). Furthermore, the failure or success of treatment cannot be determined, as the antigen may persist following appropriate antiviral treatment (65). It is also very difficult to achieve rapid detection of whole virus antigens as antigen detection usually requires high sensitivity and antigen contents in samples are generally low (66). Research on recognizing antigens and tracking antibodies requires time, as does the development of monoclonal antibodies, which are the required raw materials for immunological detection against viruses (66).

Antibody detection technology. Viral infection in the human body stimulates the production of specific antibodies. The presence of antibodies can be detected by antigen levels, which indirectly confirm 2019-nCoV infection (59). The applicable sample types for antibody detection kits are blood (including serum) plasma and whole blood. The detected antibodies are usually IgM and IgG (67). Presently, to the best of our knowledge, no systematic studies on the production and duration of these antibodies for 2019-nCoV has been performed. In general, IgM antibodies are used as an indicator of early infection, while $\mathrm{IgG}$ antibodies are used as indicators of current and previous infection $(68,69)$. Additionally, $2019-\mathrm{nCoV}$ is a mucosal infection virus and $\operatorname{IgA}$ antibodies are produced following infection (68). Briefly, the detection of specific antibodies can provide serological evidence for clinical diagnosis and help confirm the diagnosis of patients with negative nucleic acid tests in clinically suspected patients $(59,68)$. Presently, multiple units have developed 2019-nCoV IgM, IgG, IgM/IgG and total antibody on-site rapid detection kits, of which a total of 5 kits have obtained national approval (Table VI) (22).

The clinical application of the total antibody detection can improve limitations, including slow speed of nucleic acid detection in suspected patients, complex sampling, low sensitivity and the requirement for high-level biosafety measures for the control and prevention of the current 2019-nCoV epidemic (74).

Value of the combined application of nucleic acid-protein detection technology. Results from a study from the Wuhan Clinical Frontier demonstrated that the titers of virus-specific $\operatorname{IgM}$ and $\operatorname{IgG}$ in serum were often low or lower than the detection limit (27). On admission, samples were collected from patients and by day 5 almost all patients had positive or elevated antibody levels. Among them, IgM positive rates increased from $50 \%(8 / 16)$ to $81 \%(13 / 16)$ and IgG-positive rates increased from $81 \%(13 / 16)$ to $100 \%(16 / 16)(27)$. Those 
Table V. Antigen detection-related kits.

\begin{tabular}{llccc}
\hline $\begin{array}{l}\text { R\&D team } \\
\text { and product company }\end{array}$ & Detection principle & $\begin{array}{c}\text { Detection } \\
\text { time (min) }\end{array}$ & $\begin{array}{c}\text { Detection } \\
\text { target }\end{array}$ & (Refs.) \\
\hline $\begin{array}{l}\text { Tianjin University and Beijing } \\
\begin{array}{l}\text { Huaketai Company } \\
\text { Northwest University and GOLDMAG }\end{array}\end{array}$ & $\begin{array}{l}\text { Fluorescence } \\
\text { immunochromatography } \\
\text { Colloidal gold } \\
\text { immunochromatography }\end{array}$ & 15 & $\mathrm{~N}$ & Chinadevelopment (60) \\
$\begin{array}{l}\text { Sino Biological, Inc. and Guangzhou } \\
\text { Wondfo Biotech Co., Ltd }\end{array}$ & $\begin{array}{l}\text { ELISA } \\
\text { Xi'an Science and }\end{array}$ \\
\hline
\end{tabular}

R\&D, Research and Development; S, spike glycoprotein; N, nucleocapsid protein; GOLDMAG, Xi'an Gold Magnetic Nano Biotechnology Co., Ltd.

results are the exact opposite of the relatively low positive rates of detection from nucleic acid molecule testing (27). This indicated that, in the context of epidemiological history or clinical manifestations that meet diagnostic criteria, addition of immunoassays based on specific antigen-antibody responses effectively compensate for the limitations of high false-negative rated of nucleic acid detection and reduce false diagnoses. Epidemic prevention and control have a great auxiliary role and immunoassays may therefore be useful $(59,75,76)$.

A recently published study reported the latest clinical practice results at RenMin Hospital of Wuhan University in the first-line diagnosis and treatment of 2019-nCoV (72). In that study, 19 patients with negative nucleic acid tests but with clinical symptoms and CT imaging features of COVID-19 were serologically tested. The results reported that 16 patients $(84.21 \%)$ were positive for 2019-nCoV IgM antibodies and 18 patients (94.74\%) were positive for 2019-nCoV IgG antibodies. The majority of the 2019-nCoV IgM and IgG antibody detection assays have high clinical specificity and clinical detection rates, and they should be used to confirm the status of nucleic acid detection negative samples. Furthermore, in terms of treatment monitoring and disease progression, the decline and disappearance of 2019-nCoV IgM concentration and the rise of 2019-nCoV IgG concentration indicated that patients gradually recovered and produced immunity to pathogenic 2019-nCoV.

The advantage of $2019-\mathrm{nCoV}$ antibody tests is that the sample source is flexible and serum, plasma and whole blood can be obtained, avoiding the limitation of the current nucleic acid tests which collect upper respiratory tract samples and exposes medical personnel to a high exposure risk (27). Compared with PCR and sequencing, the colloidal gold test kit is easier to operate without any instruments and equipment and the assay can be performed anywhere with minimal training (55). However, China's State Drug Administration previously stated that, given the characteristics and current status of antigen/antibody detection reagents, its sensitivity and specificity are currently limited and cannot be used as the sole basis for diagnosis or exclusion of 2019-nCoV. Furthermore, it is not suitable for general population screening and can only be used as a supplement to existing viral nucleic acid detection assays $(15,21)$. In the first six editions of the 'Guidelines for the Diagnosis and Treatment of New Coronavirus Pneumonia' issued by the National Health Commission of China, the use of protein testing products is recommended to be limited to supplementary detection indicators for suspected cases of negative nucleic acid testing or used in conjunction with nucleic acid testing for the diagnosis of suspected cases $(15,21)$. However, in the 7th version of the guidelines, which were released on March 3, 2020, positive antibody tests have been included as one of the diagnostic indicators alongside positive nucleic acid tests (15). Briefly, the future application of multiple molecular diagnostic methods of nucleic acids, antigens and antibodies will shorten detection windows and increase positive detection rates. Furthermore, it will serve a crucial role in the molecular diagnosis of 2019-nCoV in laboratories.

\section{Future trends}

In the future, molecular diagnostic research of 2019-nCoV infections will speed up sample preparation, increase detection throughput and accuracy, improve detection automation level and develop novel technologies with low requirements and low costs for equipment and testing personnel $(77,78)$. Due to antibody preparation requiring additional time, faster breakthroughs are expected in pathogen nucleic acid detection technology (79).

Efficient and safe pre-processing. For RT-PCR technology, nucleic acid extraction and processing affect the yield of viral nucleic acid for analysis (80). This can be more difficult when certain sample types are used, as throat swabs and sputum often contain only trace amounts of virus (81). Efficient and fully automatic nucleic acid extraction equipment will provide better protection in terms of detection sensitivity and personnel safety (81). The Covaris ${ }^{\mathrm{TM}}$ high-performance nucleic acid release system developed by Gene Company Ltd. is processed by Adaptive Focused can completely inactivate the virus in a very short time without affecting the quality of RNA extraction (82). Furthermore, the full release of the viral nucleic acid has the advantages of fast processing, efficient recovery, stability and reliability, which enables subsequent nucleic acid purification to obtain sufficient and high-quality viral RNA (82). It is the basis for improving detection sensitivity under existing conditions and can reduce inconclusive or false-negative results (82).

Accurate quantification of viruses. According to previous reports, Apexbio-designed primer probes for Orflab and $\mathrm{N}$ sequence conserved regions of 2019-nCoV and developed a highly sensitive 


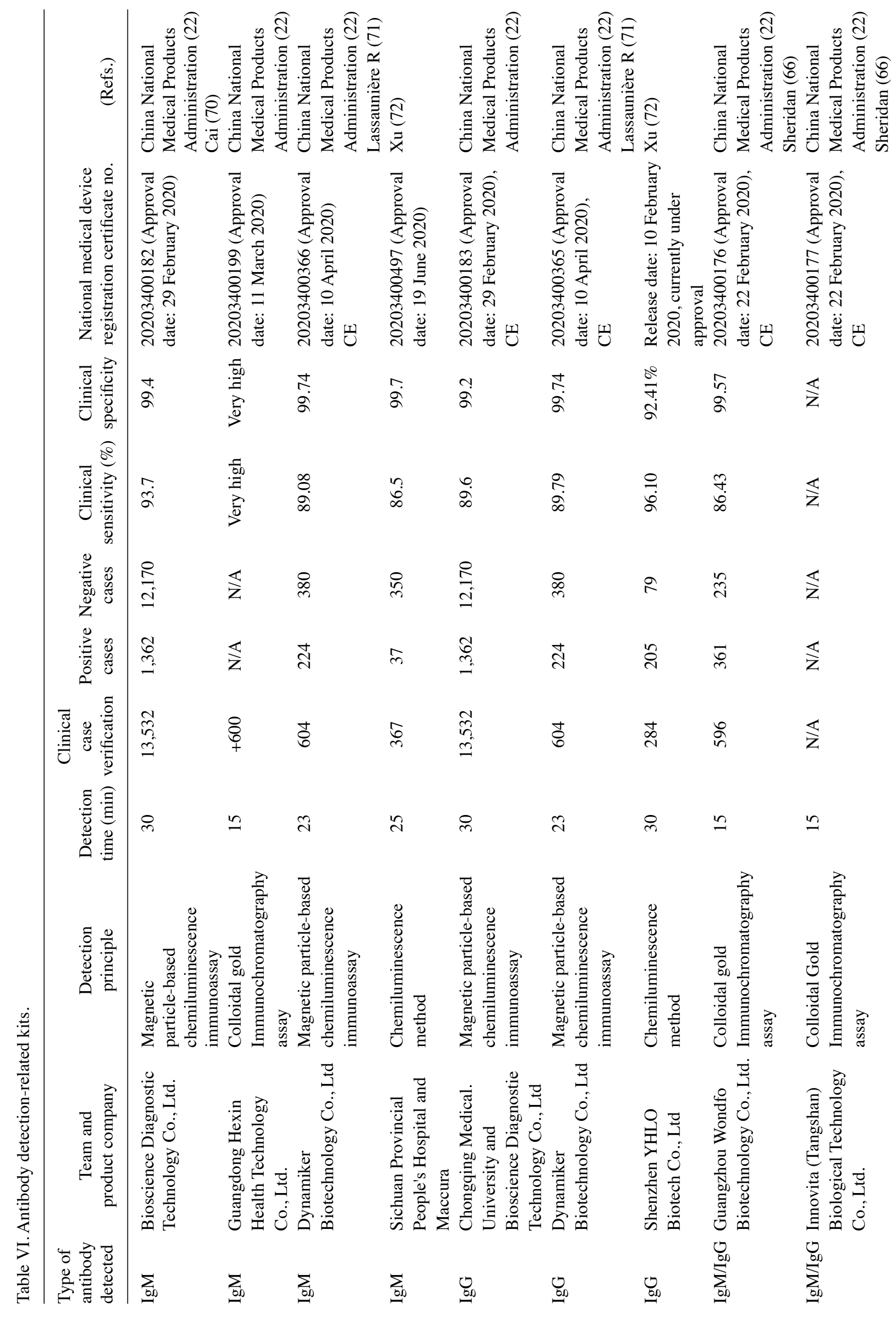




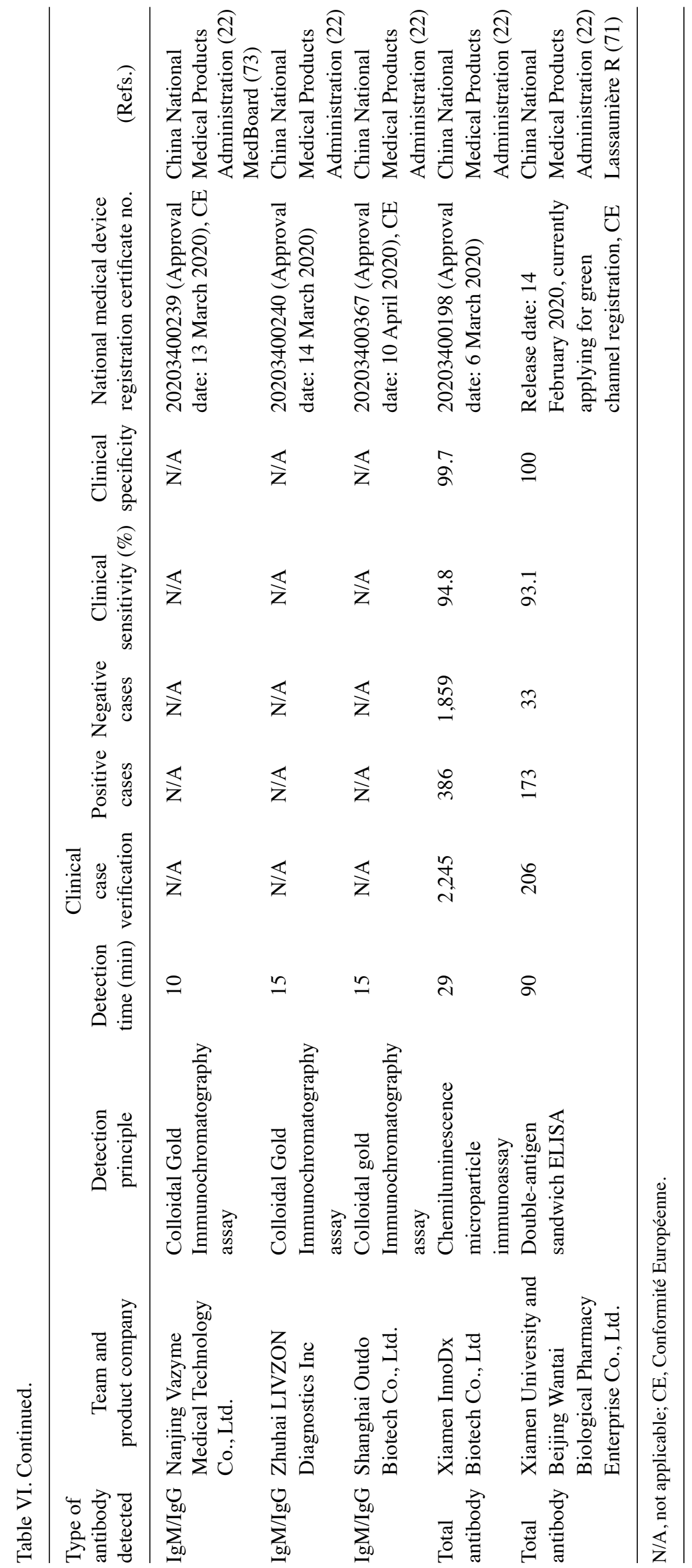


digital PCR new crown virus detection kit $(83,84)$. Compared to qPCR, digital PCR is used for the absolute quantification of nucleic acid molecules. It can directly detect the copy number of the target sequence and the detection limit can reach a single copy $(85,86)$. Furthermore, sensitivity, specificity, accuracy, resolution and tolerance is higher $(85,86)$. However, due to the high cost of equipment and tremendous workload, it is challenging to apply digital PCR to the initial stage of epidemic prevention and control, particularly in under-developed areas, on a large scale (87). However, digital PCR will still be extremely useful as it allows for absolute quantification and the detection of complex background samples, it can track the progress of disease and analyzes the viral load. Additionally, digital PCR will enable the evaluation of drug efficacy (87).

Point-of-care testing (POCT). The current technology platform used by the majority of POCT integrates nucleic acid extraction, amplification and detection on a microfluidic chip that reduces detection complexity (88). Systems presently used include GeneXpert from Danaher Corporation, as well as FilmArray from BioMérieux and Liat from Hoffmann-La Roche. Numerous domestic companies have developed nucleic acid POCT detection instruments and supporting detection reagents (66). The 2019-nCoV molecular cassette fluorescent PCR detection method launched by Transview Life can complete the detection of 4 samples in 1-1.5 h. Additionally, Orion BioScience, Inc. has completed the development of a new 2019-nCoV nucleic acid detection kit, which can detect 12 samples at a time (66).

POCT has the advantages of rapid results, unrestricted test sites and low professional skill requirements for operators (89). Therefore, the research and development of POCT nucleic acid detection technology is likely to be the general direction of future development of testing. Operators only need to add samples, such as swabs or blood, into the slot on 'sample in-result out' requirement, which will significantly simplify the detection process $(90,91)$. POCT automatically completes nucleic acid amplification, signal collection and result analysis in a short time (90). However, POCT requires improvement due to lack of authoritative control experiments and lack of uniform national standards for manufactured products (91).

Development of innovative technologies. The diagnosis of infectious diseases usually requires professional knowledge, sophisticated equipment and sufficient power sources; however, these are difficult to achieve in areas with poor economic foundations $(92,93)$. The new generation of CRISPR-based molecular diagnostic technology [such as Specific High-sensitivity Enzymatic Reporter (SHERLOCK)] $(94,95)$ do not rely on electricity as much as PCR, has lower cost, faster times and simple operation $(94,95)$. The advantages of matching the efficiency and accuracy of qPCR technology have made significant contributions to the fight against Ebola outbreaks in Nigeria, where power is often lost $(92,93)$.

In response to the 2019-nCoV epidemic, the McGovern Institute for Brain Research of the Massachusetts Institute of Technology announced on February 14, 2020, that the team of Professor Feng Zhang, the inventor of SHERLOCK technology, used synthetic COVID-19 RNA to design two crRNA recognition specific sequences for $\mathrm{S}$ and Orflab (96). If the test paper is immersed in the preliminary purified nucleic acid sample for 2-3 min, the presence of 2019-nCoV nucleic acid is determined by the appearance of black lines on the test paper (96). However, since CRISR technology has always had patent disputes, the implementation of CRISPR-based molecular diagnostic technology can be challenging from an economic perspective.

\section{Conclusion}

2019- $\mathrm{nCoV}$ has numerous methods of transmission and is highly contagious, resulting in a large number of infections within a short time frame. The most effective way to prevent and control disease is early detection, diagnosis, isolation and treatment. Therefore, how to efficiently screen for positive patients with 2019-nCoV has become the primary task for epidemic prevention. Isolating the virus strain and determining the genomic sequence provides the basis for the development of diagnostic methods and vaccines. Domestic scientific research institutes and biomedical companies in China have developed various rapid in vitro molecular diagnostic kits; however, the sensitivity, detection speed, price, ease of operation and safety varies between detection kits and there is still potential for improvement. Optimistically, the continuous development of various molecular diagnostic technologies will complement each other and improve the ability to quickly and accurately diagnose pathogens in public health emergencies, including in the 2019-nCoV epidemic.

$2019-\mathrm{nCoV}$ is a novel virus that emerged following the SARS, Ebola, Zika, bird flu and swine flu viruses, and critically endangers public health and safety. 2019-nCoV has become a global pandemic within a short time frame. The current review reported that successful virus isolation can lead to improved molecular diagnostics and effective vaccines. Currently, there is no specific treatment method for patients with $2019-\mathrm{nCoV}$ and, therefore, early diagnosis and isolation control are crucial. The development of rapid and accurate pathogen detection methods has become a top priority.

Considering the detection of highly infectious pathogens, including 2019-nCoV, must be performed in biosafety laboratories ranked Class II or above, inspectors must be fully prepared and cautious to maintain work efficiency. In the multi-country effort to combat the 2019-nCoV epidemic, multiple inspectors have been infected. Therefore, the development of a fully-automated, fully-enclosed, integrated detection system from sample extraction to signal amplification and detection is crucial to avoid high-frequency contact between the inspector and infectious samples. This is a crucial step in improving the ability to detect highly infectious pathogens.

In the future, the application of genomic technology for the detection of clinically critical and complex infections, particularly during outbreaks, need to be improved. This will aid in the early detection of epidemic pathogens, and early warnings of emergencies and emerging infectious diseases. In countries or regions where conditions permit, metagenomics detection technology capabilities should be enhanced (97). Metagenomics detection technology can quickly obtain entire genome sequences and full-length genome sequenced of samples (98). This provides a more comprehensive pathogen gene scanning analysis for critical and complex 
infections $(97,98)$. The basis for diagnosis and differential diagnosis is to determine pathogen loads, identify drug-resistant genes and guide clinical medication. However, metagenomics technology still needs to be optimized by enriching pathogen target genes, shortening testing times, simplifying the testing process and reducing the cost of testing. Thus, metagenomics technology is due to become one of the routine clinical testing technologies.

During the 2019-nCoV pandemic, numerous suspected cases and medical observers were required to perform repeated nucleic acid tests. However, detection throughput, biosafety requirements and the amount of professional inspectors are limited for RT-PCR. Numerous grass-roots hospitals cannot perform this molecular diagnosis, resulting in a large number of patients being unable to receive timely diagnosis. Therefore, it is essential to research and develop POCT technology and equipment for nucleic acids or proteins. In particular, POCT technology that employs 'sample-in result-out' should be utilized as early as possible. This would solve the difficulty of numerous primary medical institutions being unable to perform rapid molecular diagnosis.

In the future, novel epidemics or pandemics may be inevitable. It is crucial that pandemic prevention agencies perform further research on pathogen differential diagnosis technology to improve testing times, provide definitive diagnoses and to differentially diagnose diseases with similar clinical manifestations. There are various types of pneumonia-related pathogens, including 2019-nCoV, SARS-CoV, influenza virus, parainfluenza virus, adenovirus, respiratory syncytial virus, rhinovirus, mycoplasma and chlamydia. Considering RT-PCR results are time-consuming and laborious, there is an urgent need for medium-throughput detection technology for the differential diagnosis of 2019-nCoV and non-2019-nCoV conditions. In the future, it is necessary to focus on the development of high-throughput and low-cost differential diagnostic technologies. Furthermore, the development of detection technologies and supporting reagents that can simultaneously rapidly detect dozens of pathogens will be beneficial.

\section{Acknowledgements}

Not applicable.

\section{Funding}

The current review was supported by the Tianjin University 'Double First Class' Construction Talent Start-Up.

\section{Availability of data and materials}

Not applicable.

\section{Authors' contributions}

NL conceived, revised and wrote the main sections of the manuscript. PW collected literature and wrote the RT-PCR technology sections of the manuscript. XW collected literature and wrote the antibody detection technology sections of the manuscript. CG and JC collected literature and wrote the genomic characteristics and potential molecular diagnostic targets of 2019-nCoV. YG conceived the project and supervised the writing of the manuscript. All authors read and approved the final manuscript.

\section{Ethics approval and consent to participate}

Not applicable.

\section{Patient consent for publication}

Not applicable.

\section{Competing interests}

The authors declare that they have no competing interests.

\section{References}

1. Zhu N, Zhang D, Wang W, Li X, Yang B, Song J, Zhao X, Huang B, Shi W, Lu R, et al: A Novel coronavirus from patients with pneumonia in China, 2019. N Engl J Med 382: 727-733, 2020.

2. Zhou P, Yang XL, Wang XG, Hu B, Zhang L, Zhang W, Si HR, Zhu Y, Li B, Huang CL, et al: A pneumonia outbreak associated with a new coronavirus of probable bat origin. Nature 579: 270-273, 2020

3. Wu F, Zhao S, Yu B, Chen YM, Wang W, Song ZG, Hu Y, Tao ZW, Tian JH, Pei YY, et al: A new coronavirus associated with human respiratory disease in China. Nature 579: 265-269, 2020.

4. Wang C, Horby PW, Hayden FG and Gao GF: A novel coronavirus outbreak of global health concern. Lancet 395: 470-473, 2020.

5. Gorbalenya AE, Baker SC, Baric RS, de Groot RJ, Drosten C, Gulyaeva AA, Haagmans BL, Lauber C, Leontovich AM, Neuman BW, et al: Severe acute respiratory syndrome-related coronavirus: The species and its viruses-a statement of the Coronavirus Study Group. bioRXiv 2020.

6. Enserink M: Science Latest News: 'A bit chaotic.' Christening of new coronavirus and its disease name create confusion. 2020.

7. Jiang S, Shi Z, Shu Y, Song J, Gao GF, Tan W and Guo D: A distinct name is needed for the new coronavirus. Lancet 395: 949 , 2020.

8. Coronaviridae Study Group of the International Committee on Taxonomy of Viruses: The species Severe acute respiratory syndrome-related coronavirus: Classifying 2019-nCoV and naming it SARS-CoV-2. Nat Microbiol 5: 536-544, 2020.

9. Lu R, Zhao X, Li J, Niu P, Yang B, Wu H, Wang W, Song H, Huang B, Zhu N, et al: Genomic characterisation and epidemiology of 2019 novel coronavirus: Implications for virus origins and receptor binding. Lancet 395: 565-574, 2020.

10. Ahmed SF, Quadeer AA and McKay MR: Preliminary identification of potential vaccine targets for the COVID-19 coronavirus (SARS-CoV-2) based on SARS-CoV immunological studies. Viruses 12: 254, 2020.

11. Wu A, Peng Y, Huang B, Ding X, Wang X, Niu P, Meng J, Zhu Z, Zhang Z, Wang J, et al: Genome composition and divergence of the novel coronavirus $(2019-\mathrm{nCoV})$ originating in China. Cell Host Microbe 27: 325-328, 2020.

12. Zhu Z, Zhang Z, Chen W, Cai Z, Ge X, Zhu H, Jiang T, Tan W and Peng Y: Predicting the receptor-binding domain usage of the coronavirus based on kmer frequency on spike protein. Infect Genet Evol 61: 183-184, 2018.

13. Kuo L, Hurst-Hess KR, Koetzner CA and Masters PS: Analyses of coronavirus assembly interactions with interspecies membrane and nucleocapsid protein chimeras. J Virol 90: 4357-4368, 2016.

14. Nakagawa K, Lokugamage KG and Makino S: Viral and cellular mRNA translation in coronavirus-infected cells. Adv Virus Res 96: 165-192, 2016.

15. Zhao JY, Yan JY and Qu JM: Interpretations of 'Diagnosis and treatment protocol for novel coronavirus pneumonia (Trial Version 7)'. Chin Med J (Engl) 133: 1347-1349, 2020. 
16. Rothe C, Schunk M, Sothmann P, Bretzel G, Froeschl G, Wallrauch C, Zimmer T, Thiel V, Janke C, Guggemos W, et al: Transmission of 2019-nCoV infection from an asymptomatic contact in Germany. N Engl J Med 382: 970-971, 2020.

17. Lan L, Xu D, Ye G, Xia C, Wang S, Li Y and Xu H: Positive RT-PCR test results in patients recovered from COVID-19. JAMA 323: 1502-1503, 2020.

18. Yeo C, Kaushal S and Yeo D: Enteric involvement of coronaviruses: Is faecal-oral transmission of SARS-CoV-2 possible? Lancet Gastroenterol Hepatol 5: 335-337, 2020.

19. Holshue ML, DeBolt C, Lindquist S, Lofy KH, Wiesman J, Bruce H, Spitters C, Ericson K, Wilkerson S, Tural A, et al: First case of 2019 novel coronavirus in the United States. N Engl J Med 382: 929-936, 2020.

20. Xu JH, Wang SL, Zhang SX, et al: Methods for nucleic acid detection of 2019 novel coronavirus. International Journal of Laboratory Medicine. 2020 Mar; 1-19. Chinese. Available from: http://kns cnki.net/kcms/detail/50.1176.R.20200303.1428.002.html.

21. General Office of National Health Commission of the People's Republic of China. Prevention and control scheme for novel coronavirus pneumonia (version 2) [Internet]. 2020 Jan 22; Available from:http://wwwnhcgoven/jkj/s3577/202001/c67cfe29ecf1470e8c7fc47d3b751e88shtml.

22. China National Medical Products Administration. Registration information of domestic new coronavirus detection reagents. Available from: http://www.nmpa.gov.cn/WS04/CL2582/ and http://english.nmpa.gov.cn.

23. National Institute for Viral Disease Control and Prevention, Chinese Center for Disease Control and Prevention: Novel Coronavirus National Science and Technology Resource Service System[EB/OL] Feb 8, 2020; Available from: http://nmdccn/nCov/en.

24. Guo YY, Wang K, Zhang Y, et al: Comparison and analysis of the detection performance of six new coronavirus nucleic acid detection reagents. Chongqing Medicine. Feb 12, 2020; 1-11. Chinese. Available from: http://kns.cnki.net/kcms/detail $/ 50.10$ 97.R.20200212.0900.006.html.

25. Espy MJ, Uhl JR, Sloan LM, Buckwalter SP, Jones MF, Vetter EA, Yao JD, Wengenack NL, Rosenblatt JE, Cockerill FR 3rd and Smith TF: Real-time PCR in clinical microbiology: Applications for routine laboratory testing. Clin Microbiol Rev 19: 165-256, 2006.

26. Kaul KL: Laboratories and pandemic preparedness: A framework for collaboration and oversight. J Mol Diagn 22: 841-843, 2020.

27. Zhang W, Du RH, Li B, Zheng XS, Yang XL, Hu B, Wang YY, Xiao GF, Yan B, Shi ZL and Zhou P: Molecular and serological investigation of 2019-nCoV infected patients: Implication of multiple shedding routes. Emerg Microbes Infect 9: 386-389, 2020

28. Armstrong GL, MacCannell DR, Taylor J, Carleton HA, Neuhaus EB, Bradbury RS, Posey JE and Gwinn M: Pathogen genomics in public health. N Engl J Med 381: 2569-2580, 2019.

29. MGI: Rush to aid the epidemic! MGI's ultra-high-throughput sequencing system DNBSEQ-T7 facilitates rapid diagnosis of suspected patients with new coronavirus pneumonia. Jan 27 , 2020; Available from: https://www.mgitech.cn/news/213/.

30. Bowden R, Davies RW, Heger A, Pagnamenta AT, de Cesare M, Oikkonen LE, Parkes D, Freeman C, Dhalla F, Patel SY, et al: Sequencing of human genomes with nanopore technology. Nat Commun 10: 1869, 2019.

31. van Dijk EL, Jaszczyszyn Y, Naquin D and Thermes C: The third revolution in sequencing technology. Trends Genet 34: 666-681, 2018.

32. The CPC Hangzhou Municipal Committee: Two major scientific and technological projectsforepidemic prevention and control have made positive progress! Feb 12, 2020. Available from: http://wsjkwhangzhougoven/art/2020/2/18/art_1665346_41937016html.

33. Tang X, Wu C, Li X, Song Y, Yao X, Wu X, Duan Y, Zhang H, Wang Y, Qian Z, et al: On the origin and continuing evolution of SARS-CoV-2. Nat Sci Rev 7: 1012-1023, 2020.

34. Quainoo S, Coolen JPM, van Hijum SAFT, Huynen MA, Melchers WJG, van Schaik W and Wertheim HFL: Whole-genome sequencing of bacterial pathogens: The future of nosocomial outbreak analysis. Clin Microbiol Rev 30: 1015-1063, 2017.

35. Notomi T, Okayama H, Masubuchi H, Yonekawa T, Watanabe K, Amino $\mathrm{N}$ and Hase $\mathrm{T}$ : Loop-mediated isothermal amplification of DNA. Nucleic Acids Res 28: E63, 2000.

36. Shirato K, Yano T, Senba S, Akachi S, Kobayashi T, Nishinaka T, Notomi T and Matsuyama S: Detection of Middle East respiratory syndrome coronavirus using reverse transcription loop-mediated isothermal amplification (RT-LAMP). Virol J 11: 139, 2014.
37. Hong TC, Mai QL, Cuong DV, Parida M, Minekawa H, Notomi T, Hasebe F and Morita K: Development and evaluation of a novel loop-mediated isothermal amplification method for rapid detection of severe acute respiratory syndrome coronavirus. J Clin Microbiol 42: 1956-1961, 2004.

38. Shirato K, Semba S, El-Kafrawy SA, Hassan AM, Tolah AM, Takayama I, Kageyama T, Notomi T, Kamitani W, Matsuyama S and Azhar EI: Development of fluorescent reverse transcription loop-mediated isothermal amplification (RT-LAMP) using quenching probes for the detection of the Middle East respiratory syndrome coronavirus. J Virol Methods 258: 41-48, 2018.

39. Xu C, Wang H, Jin H, Feng N, Zheng X, Cao Z, Li L, Wang J, Yan F, Wang L, et al: Visual detection of Ebola virus using reverse transcription loop-mediated isothermal amplification combined with nucleic acid strip detection. Arch Virol 161: 1125-1133, 2016.

40. Yu L, Wu S, Hao X, Dong X, Mao L, Pelechano V, Chen WH and Yin X: Rapid detection of COVID-19 coronavirus using a reverse transcriptional loop-mediated isothermal amplification (RT-LAMP) diagnostic platform. Clin Chem 66: 975-977, 2020.

41. Lamb LE, Bartolone SN, Ward E and Chancellor MB: Rapid detection of novel coronavirus/severe acute respiratory syndrome coronavirus 2 (SARS-CoV-2) by reverse transcription-loop-mediated isothermal amplification. PLoS One 15: e0234682, 2020.

42. Li Y, Fan P, Zhou S and Zhang L: Loop-mediated isothermal amplification (LAMP): A novel rapid detection platform for pathogens. Microb Pathog 107: 54-61, 2017.

43. Piepenburg O, Williams CH, Stemple DL and Armes NA: DNA detection using recombination proteins. PLoS Biol 4: e204, 2006.

44. National Institute for Viral Disease Control and Prevention, Chinese Center For Disease Control and Prevention. New Coronavirus (2019-nCoV) nucleic acid isothermal amplification rapid detection kit completed 3 clinical evaluations. Available from: http://ivdc. chinacdc.cn/kyjz/202002/t20200207_212372.html.

45. Karas M,Glückmann M and SchäferJ: Ionization in matrix-assisted laser desorption/ionization: Singly charged molecular ions are the lucky survivors. J Mass Spectrom 35: 1-12, 2000.

46. Gao X, Tan BH, Sugrue RJ and Tang K: MALDI mass spectrometry for nucleic acid analysis. Top Curr Chem 331: 55-77, 2013.

47. Jang KS and Kim YH: Rapid and robust MALDI-TOF MS techniques for microbial identification: A brief overview of their diverse applications. J Microbiol 56: 209-216, 2018.

48. Li M, Jiang XW, Liang ZK, et al: Application Value of Common Molecular Diagnostic Techniques in Detection of New Coronavirus. Chinese Journal of Clinical Laboratory. 2020. Author's manuscript available at https://www.ddm 360 . com/apparticle/detail/1022.

49. Gao Y, Huang X, Zhu Y and Lv Z: A brief review of monoclonal antibody technology and its representative applications in immunoassays. J Immunoassay Immunochem 39: 351-364, 2018.

50. Huang C, Wen T, Shi FJ, Zeng XY and Jiao YJ: Rapid detection of IgM antibodies against the SARS-CoV-2 virus via colloidal gold nanoparticle-based lateral-flow assay. ACS Omega 5: 12550-12556, 2020.

51. Nuccetelli M, Pieri M, Grelli S, Ciotti M, Miano R, Andreoni M and Bernardini S: SARS-CoV-2 infection serology: A useful tool to overcome lockdown? Cell Death Discov 6: 38, 2020.

52. Lippi G, Salvagno GL, Pegoraro M, Militello V, Caloi C, Peretti A, Gaino S, Bassi A, Bovo C and Lo Cascio G: Assessment of immune response to SARS-CoV-2 with fully automated MAGLUMI 2019-nCoV IgG and IgM chemiluminescence immunoassays. Clin Chem Lab Med 58: 1156-1159, 2020.

53. Padoan A, Cosma C, Sciacovelli L, Faggian D and Plebani M: Analytical performances of a chemiluminescence immunoassay for SARS-CoV-2 IgM/IgG and antibody kinetics. Clin Chem Lab Med 58: 1081-1088, 2020.

54. Aydin S: A short history, principles, and types of ELISA, and our laboratory experience with peptide/protein analyses using ELISA. Peptides 72: 4-15, 2015.

55. Kong D, Liu L, Song S, Suryoprabowo S, Li A, Kuang H, Wang $\mathrm{L}$ and $\mathrm{Xu} \mathrm{C}$ : A gold nanoparticle-based semi-quantitative and quantitative ultrasensitive paper sensor for the detection of twenty mycotoxins. Nanoscale 8: 5245-5253, 2016.

56. Wu HS, Chiu SC, Tseng TC, Lin SF, Lin JH, Hsu YH, Wang MC, Lin TL, Yang WZ, Ferng TL, et al: Serologic and molecular biologic methods for SARS-associated coronavirus infection, Taiwan. Emerg Infect Dis 10: 304-310, 2004.

57. Gan SD and Patel KR: Enzyme immunoassay and enzyme-linked immunosorbent assay. J Invest Dermatol 133: e12, 2013. 
58. Seo G, Lee G, Kim MJ, Baek SH, Choi M, Ku KB, Lee CS, Jun S, Park D, Kim HG, et al: Rapid detection of COVID-19 causative virus (SARS-CoV-2) in human nasopharyngeal swab specimens using field-effect transistor-based biosensor. ACS Nano 14: 5135-5142, 2020.

59. Lee CY, Lin RT, Renia L and Ng LF: Serological approaches for COVID-19: epidemiologic perspective on surveillance and control. Front Immunol 11: 879, 2020.

60. Chinadevelopment. Tianjin University and company jointly develop new kits to quickly detect new coronavirus in 15 minutes. 2020.02.10. Available from: http://www.chinadevelopment.com. $\mathrm{cn} / \mathrm{sh} / 2020 / 0210 / 1607218 . s h t m l$.

61. Xi'an Science and Technology Bureau, Xi'an Foreign Experts Bureau. Xi'an Jinci Nanobiology has developed a new detection reagent for coronavirus. 2020.02.19. Available from: http://xakj. xa.gov.cn $/ \mathrm{kjdt} / \mathrm{mtbd} / 5 \mathrm{e} 3 \mathrm{fc} 58 \mathrm{~d} 65 \mathrm{cbd} 812356 \mathrm{eb} 239 . \mathrm{html}$.

62. Bao L, Deng W and Gao H: Reinfection could not occur in SARS-CoV-2 infected rhesus macaques. medRxiv. DOI. 10.1101/2020.03.13.990226. Author's manuscript available at https://www.biorxiv.org/content/10.1101/2020.03.13.990226v1. full.pdf.

63. Deng W, Bao L, Gao H, Xiang Z, Qu Y, Song Z, Gong S, Liu J, Liu J, Yu P, et al: Rhesus macaques can be effectively infected with SARS-CoV-2 via ocular conjunctival route. bioRxiv.2020

64. Porte L, Legarraga P, Vollrath V, Aguilera X, Munita JM, Araos R, Pizarro G, Vial P, Iruretagoyena M, Dittrich S and Weitzel T: Evaluation of novel antigen-based rapid detection test for the diagnosis of SARS-CoV-2 in respiratory samples. Int J Infect Dis: Jun 1, 2020 (Epub ahead of print). doi: 10.1016/j.ijid.2020.05.098.

65. Theel ES, Slev P, Wheeler S, Couturier MR, Wong SJ and Kadkhoda K: The role of antibody testing for SARS-CoV-2: Is there one? J Clin Microbiol 58: e00797, 2020.

66. Sheridan C: Fast, portable tests come online to curb coronavirus pandemic. Nat Biotechnol 38: 515-518, 2020.

67. Li Z, Yi Y, Luo X, Xiong N, Liu Y, Li S, Sun R, Wang Y, Hu B Chen $\mathrm{W}$, et al: Development and clinical application of a rapid IgM-IgG combined antibody test for SARS-CoV-2 infection diagnosis. J Med Virol: Feb 27, 2020 (Epub ahead of print). doi: 10.1002/jmv.25727. Online ahead of print

68. Jacofsky D, Jacofsky EM and Jacofsky M: Understanding antibody testing for COVID-19. J Arthroplasty 35 (7S): S74-S81, 2020

69. Shu H, Wang S, Ruan S, Wang Y, Zhang J, Yuan Y, Liu H, Wu Y, Li R, Pan S, et al: Dynamic changes of antibodies to SARS-CoV-2 in COVID-19 patients at early stage of outbreak. Virol Sin: Jul 27, 2020 (Epub ahead of print). doi: 10.1007/ s12250-020-00268-5.

70. Cai XF, Chen J, Li Hu J, Long QX, Deng HJ, Liu P, Fan K, Liao P, Liu BZ, Wu GC, et al: A peptide-based magnetic chemiluminescence enzyme immunoassay for serological diagnosis of coronavirus disease 2019. J Infect Dis 222: 189-193, 2020.

71. Lassaunière R, Frische A, Harboe ZB, Nielsen AC, Fomsgaard A Krogfelt KA and Jørgensen CS: Evaluation of nine commercial SARS-CoV-2 immunoassays. Available at: https://www.medrxiv. org/content/medrxiv/early/2020/02/25/2020.02.22.20026617.full. pdf.

72. Xu WZ, Li J, He XY, Zhang C, Mei S, Li C, Li Y, Cheng S and Zhang P: The diagnostic value of joint detection of serum IgM and IgG antibodies to $2019-\mathrm{nCoV}$ in $2019-\mathrm{nCoV}$ infection. Chin J Lab Med 43: 230-233, 2020.

73. MedBoard: Test Products and New Approvals. Available from: https://www.medboardco.com/covid-19-products/.

74. Ministry of ScienceandTechnologyofthePeople'sRepublicofChina Xiamen University jointly developed the first rapid detection kit for 2019-nCoV antibody.2020. Available from: http://wwwsafeagoven/dfkj/fj/zxdt/202002/t20200224_151881htm.

75. Okba NMA, Müller MA, Li W, Wang C, GeurtsvanKessel CH, Corman VM, Lamers MM, Sikkema RS, de Bruin E, Chandler FD, et al: Severe acute respiratory syndrome coronavirus 2-specific antibody responses in coronavirus disease patients. Emerg Infect Dis 26: 1478-1488, 2020.

76. Cutts FT and Hanson M: Seroepidemiology: An underused tool for designing and monitoring vaccination programmes in low- and middle-income countries. Trop Med Int Health 21: 1086-1098, 2016

77. Chan JF, Yip CC, To KK, Tang TH, Wong SC, Leung KH, Fung AY, Ng AC, Zou Z, Tsoi HW, et al: Improved molecular diagnosis of COVID-19 by the novel, highly sensitive and specific COVID-19-RdRp/Hel real-time reverse transcription-PCR assay validated in vitro and with clinical specimens. J Clin Microbiol 58: e00310-20, 2020.
78. Tahmasebi S, Khosh E and Esmaeilzadeh A: The outlook for diagnostic purposes of the 2019-novel coronavirus disease. J Cell Physiol: May 26, 2020 (Epub ahead of print). doi: 10.1002/ jcp.29804.

79. Yan Y, Chang L and Wang L: Laboratory testing of SARS-CoV, MERS-CoV, and SARS-CoV-2 (2019-nCoV): Current status, challenges, and countermeasures. Rev Med Virol 30: e2106, 2020.

80. Hata A, Katayama H, Kitajima M, Visvanathan C, Nol C and Furumai H: Validation of internal controls for extraction and amplification of nucleic acids from enteric viruses in water samples. Appl Environ Microbiol 77: 4336-4343, 2011

81. Tahamtan A and Ardebili A: Real-time RT-PCR in COVID-19 detection: Issues affecting the results. Expert Rev Mol Diagn 20: 453-454, 2020

82. Nauwelaers D, Vijgen L, Atkinson C, Todd A, Geretti AM, Van Ranst M and Stuyver L: Development of a real-time multiplex RSV detection assay for difficult respiratory samples, using ultrasone waves and MNAzyme technology. J Clin Virol 46: 238-243, 2009.

83. Toms D, Li J and Cai HY: Evaluation of WHO listed COVID-19 qPCR primers and probe in silico with 375 SERS-CoV-2 full genome sequences. medRxiv: April 28, 2020 (Epub ahead of print). doi: https://doi.org/10.1101/2020.04.22.20075697.

84. Yan C, Cui J, Huang L, Du B, Chen L, Xue G, Li S, Zhang W, Zhao L, Sun Y, et al: Rapid and visual detection of 2019 novel coronavirus (SARS-CoV-2) by a reverse transcription loop-mediated isothermal amplification assay. Clin Microbiol Infect 26: 773-779, 2020

85. Vogelstein B and Kinzler KW: Digital PCR. Proc Natl Acad Sci USA 96: 9236-9241, 1999.

86. Sykes PJ, Neoh SH, Brisco MJ, Hughes E, Condon J and Morley AA: Quantitation of targets for PCR by use of limiting dilution. Biotechniques 13: 444-449, 1992.

87. Li H, Bai R, Zhao Z, Tao L, Ma M, Ji Z, Jian M, Ding Z, Dai X, Bao F and Liu A: Application of droplet digital PCR to detect the pathogens of infectious diseases. Biosci Rep 38: BSR20181170, 2018.

88. Magro L, Jacquelin B, Escadafal C, Garneret P, Kwasiborski A, Manuguerra JC, Monti F, Sakuntabhai A, Vanhomwegen J, Lafaye $\mathrm{P}$ and Tabeling P: Paper-based RNA detection and multiplexed analysis for Ebola virus diagnostics. Sci Rep 7: 1347, 2017.

89. Khan AH, Shakeel S, Hooda K, Siddiqui K and Jafri L: Best practices in the implementation of a point of care testing program: Experience from a tertiary care hospital in a developing country. EJIFCC 30: 288-302, 2019.

90. Park S, Zhang Y, Lin S, Wang TH and Yang S: Advances in microfluidic PCR for point-of-care infectious disease diagnostics. Biotechnol Adv 29: 830-839, 2011.

91. Basile K, Kok J and Dwyer DE: Point-of-care diagnostics for respiratory viral infections. Expert Rev Mol Diagn 18: 75-83, 2018.

92. Broadhurst MJ, Brooks TJ and Pollock NR: Diagnosis of Ebola virus disease: Past, Present, and Future. Clin Microbiol Rev 29: 773-793, 2016.

93. Shorten RJ, Brown CS, Jacobs M, Rattenbury S, Simpson AJ and Mepham S: Diagnostics in Ebola virus disease in resource-rich and resource-limited settings. PLoS Negl Trop Dis 10: e0004948, 2016.

94. Gootenberg JS, Abudayyeh OO, Lee JW, Essletzbichler P, Dy AJ, Joung J, Verdine V, Donghia N, Daringer NM, Freije CA, et al: Nucleic acid detection with CRISPR-Cas13a/C2c2. Science 356: 438-442, 2017.

95. Kellner MJ, Koob JG, Gootenberg JS, Abudayyeh OO and Zhang F: SHERLOCK: Nucleic acid detection with CRISPR nucleases. Nat Protoc 14: 2986-3012, 2019.

96. Zhang F, Abudayyeh OO and Gootenberg JS: A protocol for detection of COVID-19 using CRISPR diagnostics. (v20200321) 2020. Available from: https://www.broadinstitute.org/files/publications/special/COVID-19\%20detection\%20(updated).pdf.

97. Gu W, Miller S and Chiu CY: Clinical metagenomic next-generation sequencing for pathogen detection. Annu Rev Pathol 14: 319-338, 2019.

98. Chiu CY and Miller SA: Clinical metagenomics. Nat Rev Genet 20: 341-355, 2019.

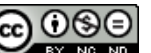

This work is licensed under a Creative Commons Attribution-NonCommercial-NoDerivatives 4.0 International (CC BY-NC-ND 4.0) License. 